\title{
The Application of Tissue Glue in Eyelid Laceration Repair in Children During the Coronavirus Disease 2019 Pandemic Lockdown in Wuhan
}

\author{
Hua Yuan* \\ Yu-Zhao Zhang* \\ Hong Jie \\ Shi-Lian Li
}

Department of Ophthalmology, Wuhan Children's Hospital (Wuhan Maternal and Child Healthcare Hospital), Tongji

Medical College, Huazhong University of Science \& Technology, Wuhan, 430016,

People's Republic of China

*These authors contributed equally to this work
Correspondence: Shi-Lian Li

Department of Ophthalmology, Wuhan

Children's Hospital (Wuhan Maternal and

Child Healthcare Hospital), Tongii Medical

College, Huazhong University of Science

\& Technology, No. 100 Hongkong Road,

Wuhan, 430016, People's Republic of

China

Tel +86 I397| 2 I 2408

Fax +8627-82433375

Email lisldrli@।63.com
Objective: To discuss a rapid and effective treatment used for children with eyelid lacerations during the COVID-19 lockdown in Wuhan to limit the risk of cross-infection.

Methods: A comparative study was conducted of forty-five patients with eyelid lacerations who attended the Ophthalmology Department of Wuhan Children's Hospital between January 23, 2020 and March 6, 2020. The tissue glue Histoacryl was used to bond the wounds in 24 cases, while the traditional suture method was used for 21 cases. The wound healing time, complications, treatment satisfaction, and number of visits of the two groups were compared.

Results: The two groups had similar baseline characteristics. The wound healing time (from wound disinfection to wound dressing) was shorter in the tissue glue group $(4.35 \pm 0.47 \mathrm{~min}$ versus $11.71 \pm 1.85 \mathrm{~min}, P<0.01)$. There was 1 case of wound dehiscence in the tissue glue group. Twenty-two cases in the tissue glue group were satisfied, 2 cases were basically satisfied, and 0 were dissatisfied. Eleven cases in the traditional suture group were satisfied, 9 cases were basically satisfied, and 1 case was dissatisfied. The difference was statistically significant $(P<0.05)$. In terms of the number of visits, the tissue glue group visited $(1.54 \pm$ $0.88)$ times, while the traditional suture group visited $(2.38 \pm 0.59)$ times. The difference between the two groups was statistically significant $(P<0.01)$. The real-time reverse transcriptase polymerase chain tests for severe acute respiratory syndrome coronavirus 2 of all medical staff in the ophthalmology emergency room were negative.

Conclusion: Compared with the traditional suture method, tissue glue used in eyelid laceration in children has the advantages of painlessness, shorter operation duration, higher safety and satisfaction, greater ease of care, and fewer hospital visits. Tissue glue can be widely used to reduce the risk of cross-infection.

Keywords: coronavirus disease 2019, COVID-19, tissue glue, acrylate cyanide, children, eyelid, laceration

\section{Introduction}

Eyelid lacerations are a common injury faced by ophthalmologists in the emergency room. It is reported that facial soft tissue trauma is a common injury and comprises roughly $10 \%$ of all emergency room visits, ${ }^{1}$ and children often present with eyelid lacerations in the ophthalmology emergency room. Eyelid lacerations are traditionally sealed with sutures.

In December 2019, the coronavirus disease 2019 (COVID-19) pandemic began to spread in Wuhan, Hubei. ${ }^{2}$ On January 12, 2020, the World Health Organization 
named the virus 2019-nCoV. ${ }^{3}$ On January 23, 2020, Wuhan implemented blockade management, and by March 6, 2020, a total of 80,651 confirmed cases had been reported in China. ${ }^{4}$ As Wuhan city had been under lockdown since January 23th, the medical services were under a great deal of pressure, resulting in a shortage of medical resources for non-COVID-19 patients.

During the COVID-19 pandemic, a patient's temperature and medical history were usually recorded in the emergency pre-examination and triage system. However, this system could not exclude potential patients with a virus infection. Ophthalmic examinations or operations were mostly performed close-up, and the longer the operation the greater the risk of infection exposure was. In addition, some children were reluctant to wear face masks. Traditional suturing needs local anesthetics or general anesthesia and long operation time, which increases the risk of transmission of 2019-nCoV. Therefore, dealing with wounds quickly and effectively to reduce pain and injury $^{5}$ as well as reducing the risk of cross-infection became new challenges faced by ophthalmologists during the pandemic. The aesthetic outcome was also important for children. Previous reports showed that tissue glue was used for the cutaneous closure of lacerations and cesarean delivery and laparoscopic wounds. ${ }^{6,7}$ Adhesion of skin wounds with tissue glue had the advantages of short procedure duration, painlessness. During the lockdown of Wuhan, tissue glue was used in our department in children with eyelid lacerations, and the effects were compared with those of the traditional suture method.

\section{Objects and Methods}

\section{Objects}

This was a comparative study. Pediatric patients under 18 years of age with eyelid laceration were included, while patients with serious systemic diseases or eyelid margin laceration or canaliculus laceration or levator palpebrae superioris muscle lacerations were excluded. A total of 45 children with eyelid lacerations who attended the Department of Ophthalmology of Wuhan Children's Hospital between January 23, 2020, and March 6, 2020, were included. The data of the clinical characteristics of the wound were recorded, consisting of healing time, complications, satisfaction, and number of visits. Ophthalmologists objectively introduced the two treatment options. The children were assigned to one of two groups, the tissue glue group or the traditional suture group, depending on the choice of their legal guardians.

\section{Materials}

Either N-butyl-2-cyanoacrylate (Histoacryl Blue, HAB, Belang, Germany) or 6-0 absorbable suture (Johnson \& Johnson, USA) was used to treat the lacerations.

\section{Methods}

The patients entered and exited the emergency department through a special channel. Temperature and medical history were recorded before examination. Tertiary personal protective equipment was used (disposable surgical caps, medical protective masks [N95 respirator], goggles/face screens, impermeable isolation gowns/protective clothing, gloves, and shoe covers). Natural saline and hydrogen peroxide were used to rinse the wounds slowly and avoid autoclaving them with syringes. The wounds were examined and carefully debrided, along with complete hemostasis and disinfection.

Tissue glue was designed for wound closure without anesthesia. The heads of the patients in the tissue glue group were held firmly by a family member, while the wounds were pressed gently with dry gauze to stop the bleeding and keep the wounds dry. Following this, fingers or instruments were used to pull the edges of both sides of the wounds together tightly to align the skin edges. Glue was applied to the wounds at least $0.5 \mathrm{~cm}$ from the wound edge, and the wounds were pressed for 30 seconds until the glue dried and turned white. ${ }^{8}$ A pressure dressing was applied for $24 \mathrm{~h}$ postoperatively, and no dressing change was required. Staged application of the glue was used for irregular or long wounds. It was important to apply a small amount of glue when treating wounds near the eyelid margin and use cotton swabs or gauze to protect the eye and prevent glue from entering the eye or causing eyelash adhesion. Furthermore, care was taken not to apply the glue to the inside of the wound, which could cause an inflammatory reaction that would prevent healing. ${ }^{9}$ Tissue glue could not be used on wounds with acute purulent infection or human or animal bites. ${ }^{10}$

In the traditional suture group, the subcutaneous tissues were sutured in layers under local infiltration anesthesia ( $2 \%$ lidocaine), with a final interrupted suture of the skin using 6-0 absorbable sutures. A pressure dressing was applied for $24 \mathrm{~h}$ postoperatively, and the sutures were removed seven days after surgery. 
The data collected concerned the patient's age, sex, wound length, injury time, wound healing time, and treatment satisfaction, as well as the number of visits the patient made and any complications that occurred. Injury time referred to the period between suffering the injury and arriving at the hospital. The wound healing time referred to the duration from wound disinfection to wound dressing. Complications referred to obvious symptoms of wound infection or wound dehiscence, and any complications that arose were reported a week after the hospital treatment by telephone. The sutures were removed in the traditional suture group a week afterwards, as well. The treatment satisfaction investigation was carried out three months afterwards by telephone or online questionnaire. The treatment satisfaction ratings of the parents were classified into unsatisfactory (usually wide, unsightly, or hypertrophic scarring), moderately satisfactory (usually local, visible scarring), and satisfactory (almost imperceptible scarring). The number of visits referred to the number of visits made to the Department of Ophthalmology from injury to seven days after treatment.

\section{Statistical Analysis}

SPSS 21.0 software was used for the data analysis. Continuous data were expressed as mean \pm standard deviation, and they were compared with an independent samples $t$-test. Countable data were presented with frequency and percentage and compared with a $\chi^{2}$ test or a Fisher's exact probability test. The Wilcoxon test was used to calculate the difference for the ordered categorical variables. The significance level was set at $\alpha=0.05$, and $P<$ 0.05 was considered statistically significant.

\section{Results}

There were 24 cases in the tissue glue group and 21 cases in the traditional suture group. Thirty-six cases were males $(80 \%)$. The youngest patient was 1.25 years-old and the oldest one was 7.58 years-old. The average age of the patients was $(2.83 \pm 1.54)$ years old. The wound lengths ranged from 1 (centimeter, $\mathrm{cm}$ ) to $5 \mathrm{~cm}$. The common cause of injury was accidental collisions with furniture at home. All cases saw a doctor within 6 hours. There was no statistically difference between the two groups in the baseline characteristics including age, gender, wound length, injury time (Table 1).
Table I General Information of Patients

\begin{tabular}{|l|c|c|c|c|}
\hline Characteristics & $\begin{array}{c}\text { Tissue } \\
\text { Glue } \\
\text { Group } \\
(\mathbf{n}=\mathbf{2 4})\end{array}$ & $\begin{array}{c}\text { Traditional } \\
\text { Suture } \\
\text { Group } \\
(\mathbf{n}=\mathbf{2} \mathrm{I})\end{array}$ & $\mathbf{t} / \chi^{2}$ & $\mathbf{P}$ value \\
\hline Age(years) & $2.88 \pm 1.62$ & $2.76 \pm 1.45$ & $0.24^{\mathrm{a}}$ & $0.8 \mathrm{I}$ \\
\hline $\begin{array}{l}\text { Sex } \\
\text { Male } \\
\text { Female }\end{array}$ & $\begin{array}{c}20(83.33) \\
4(16.67)\end{array}$ & $\begin{array}{c}16(76.19) \\
5(23.8 I)\end{array}$ & $0.05^{\mathrm{b}}$ & 0.82 \\
\hline $\begin{array}{l}\text { Injury time(h) } \\
\text { (Time between } \\
\text { injury and arrival } \\
\text { at hospital) }\end{array}$ & $0.73 \pm 0.43$ & $0.70 \pm 0.36$ & $0.24^{\mathrm{a}}$ & 0.82 \\
\hline $\begin{array}{l}\text { Wound } \\
\text { length(cm) }\end{array}$ & $2.50 \pm 1.28$ & $2.57 \pm 1.07$ & $-0.20^{\mathrm{a}}$ & 0.85 \\
\hline
\end{tabular}

Notes: a Independent-samples $t$-test. ${ }^{b} \mathrm{Chi}$-square test.

Abbreviations: $\mathrm{h}$, hours; $\mathrm{cm}$, centimeter.

\section{The Operation Duration Between the Two Groups}

The wound healing time was $(4.35 \pm 0.47) \mathrm{min}$ in the tissue glue group and $(11.71 \pm 1.85) \mathrm{min}$ in the traditional suture group, respectively. The wound healing time was significantly shorter in the tissue glue group than that in the traditional suture group, and the difference was statistically significant $(t=-17.74, P<0.01)$.

\section{Comparison of Complications}

There were no wound infections in either group. One patient in the tissue glue group had wound dehiscence which healed spontaneously.

\section{Treatment Satisfaction}

In the tissue glue group, 22 cases were satisfied with two cases basically satisfied and no case dissatisfied. In the traditional suture group, 11 cases were satisfied, nine cases were basically satisfied, and one case was dissatisfied. The treatment satisfaction in the tissue glue group was significantly higher than that of the traditional suture group, and the difference was statistically significant $(Z=-2.26, P<0.05)$.

\section{Number of Visits}

The number of visits to the Department of Ophthalmology from injury to seven days postoperatively in the tissue group was $(1.54 \pm 0.88)$ times, while the traditional suture group was $(2.38 \pm 0.59)$ times. The number of visits in the 
Table 2 Comparison of Evaluation Indicators Between Tissue Glue Group and Traditional Suture Group

\begin{tabular}{|l|c|c|c|c|}
\hline $\begin{array}{l}\text { Evaluation } \\
\text { Indicators }\end{array}$ & $\begin{array}{c}\text { Tissue } \\
\text { Glue } \\
\text { Group } \\
(\mathbf{n}=\mathbf{2 4})\end{array}$ & $\begin{array}{c}\text { Traditional } \\
\text { Suture } \\
\text { Group } \\
(\mathbf{n}=\mathbf{2 1})\end{array}$ & $\mathbf{t} / \mathbf{Z}$ & P value \\
\hline $\begin{array}{l}\text { Wound healing time } \\
\text { (min, Mean } \pm \text { SD) }\end{array}$ & $4.35 \pm 0.47$ & $\mathrm{II} .71 \pm 1.85$ & $-17.74^{\mathrm{a}}$ & 0.00 \\
\hline $\begin{array}{c}\text { Complications [n(\%)] } \\
\text { Infection } \\
\text { Wound dehiscence }\end{array}$ & $\begin{array}{c}0 \\
\mathrm{I}(4.17)\end{array}$ & 0 & & \\
\hline $\begin{array}{c}\text { Satisfaction [n (\%)] } \\
\text { Dissatisfied } \\
\text { Basically satisfied } \\
\text { Satisfied }\end{array}$ & $\begin{array}{c}2(8.33) \\
22(9 \mathrm{I} .67)\end{array}$ & $\begin{array}{c}\mathrm{I}(4.76) \\
\mathrm{II}(52.38)\end{array}$ & $-2.26^{\mathrm{b}}$ & 0.02 \\
\hline $\begin{array}{l}\text { The number of hospital } \\
\text { visit(Mean } \pm \text { SD) }\end{array}$ & $\mathrm{I} .54 \pm 0.88$ & $2.38 \pm 0.59$ & $-3.56^{\mathrm{b}}$ & 0.00 \\
\hline
\end{tabular}

Notes: ${ }^{\mathrm{a}}$ Independent-samples $t$-test. ${ }^{\mathrm{b}}$ mann-Whitney $U$-test. Abbreviation: min, minutes.

tissue group was less than that of the traditional suture group, and the difference was statistically significant $(P<0.01)$. The data were summarized in Table 2 . Fortunately, during follow-up, the tests of severe acute respiratory syndrome coronavirus 2 (SARS-Cov-2) realtime reverse transcriptase polymerase chain (RT-PCR) of upper respiratory swabbing specimen for all medical staff at ophthalmology emergency room were negative.

\section{Discussion}

$2019-\mathrm{nCoV}$ is a $\beta$ class coronavirus that is highly pathogenic and extremely contagious. This is the reason why it spread at such an astonishing speed and caused a global pandemic. Home isolation orders were implemented in Wuhan on January 23, 2020 to prevent the spread of COVID-19. During this period of home isolation, eyelid lacerations became the most common ocular trauma presenting at our pediatric ophthalmology department. Therefore, the question of how to treat patients noninvasively, quickly, and painlessly while at the same time minimizing the risk of infection exposure and preventing the spread of the disease was in urgent need of a response.

Traditional suturing is the standard method for treating traumatic wounds. However, this approach carries a variety of disadvantages, such as the need for a local injection of anesthetic or general anesthesia, which can be painful for children. Moreover, in the case of general anesthesia, tracheal intubation is essential, ${ }^{1,11}$ but it would also increase the risk of aerosol transmission of COVID-19. Furthermore, dressing changes and the removal of sutures are necessary with traditional suturing, so patients and their families have to attend multiple follow-up visits, which increases both the mental stress and exposure to high-risk environments. Due to traffic blocks, follow-up visits at the hospital also had their limitations and difficulties during the period of the Wuhan lockdown.

Tissue glue first began to be used in humans in 1960 and became more widely available in 1970. The most commonly used tissue glues are butyl cyanoacrylate (Histoacryl), dioctyl-2-cyanoacrylate, and fibrin adhesives. The main component of tissue glue (Histoacryl) is the monomer N-butyl-2-cyanoacrylate, which rapidly polymerizes and solidifies on contact with human tissue fluid, forming a thin film and producing strong adhesion to the wound. Tissue glue has the advantage of being painless, non-invasive, antimicrobial, hemostatic, aesthetically pleasing, and quick to use. Furthermore, no suture removal or anesthesia is required, and the technique is economical. $^{12-16}$ The tissue glue used in intraocular surgery has also achieved good results. Kumar et al reported that both glued aniridia intraocular lenses (IOL) and glued IOL/iridoplasty showed good functional and anatomical results in eyes with a lens capsule or iris deficiency. ${ }^{17}$ In our study, the tissue glue group had a shorter healing time, higher patient satisfaction, and fewer visits compared with the traditional suture group, which made it less likely for them to be infected with and spread COVID-19.

Previous research showed that there was no difference between the use of tissue glue for trauma wound by trained beginners and experienced clinicians, which demonstrated that the operative skills can be acquired quickly. ${ }^{18}$ Moreover, from the viewpoint of medical staff, operating with tissue glue is simple, and it has a short disposal duration. Thus, to a certain extent, the use of tissue glue can save labor costs, ensure medical quality, and reduce the consumption of medical resources. ${ }^{19}$ In the present study, there was one case of wound dehiscence in the tissue glue group, which was $1 \mathrm{~cm}$ long and located in the eyelid. The parents stated that the wound was slightly open because the child had rubbed the wound with hand. The parents did not bring the child to the hospital, and the wound healed spontaneously. According to a Cochrane study, evidence that tissue glue had a higher risk of wound dehiscence than sutures was insufficient, ${ }^{11,19}$ but subtle statistical differences in wound dehiscence have 
been documented for tissue glue compared with conventional sutures. ${ }^{11}$ Blondeel et al showed that tissue glue and sutures performed consistently in closing long or short surgical wounds, ${ }^{20}$ while Jenkins et al noted that tissue glue had the same tensile strength as $5-0$ non-absorbable sutures. ${ }^{15}$ However, it is recommended that high-tension wounds should be closed with subcutaneous sutures before gluing the skin with tissue glue, and liquid or ointments should not be applied after gluing a wound with tissue glue, as they can cause the tissue glue to loosen and fall off. $^{21}$ In our study, the children's injuries were relatively minor, as both children and their parents were isolated at home during the outbreak of the pandemic. It has been reported that tissue glue can replace traditional sutures in the treatment of simple trauma. ${ }^{16}$

Fortunately, at the end of the study, the results of the coronavirus nucleic acid test for all the medical staff in the ophthalmology emergency room were negative.

This study has several limitations. During the lockdown of Wuhan, randomizing patients was difficult. Patients were selected for the two groups according to the choice of their legal guardians. In addition, this study did not address potential bias through sensitivity analysis. Nevertheless, as an emergency treatment method during the COVID-19 epidemic, tissue glue has obvious advantages in the treatment of child eyelid laceration.

\section{Conclusion}

Compared with traditional suturing, tissue glue greatly reduced wound healing time and had the advantages of being painless, non-invasive, and highly satisfactory as well as not requiring postoperative dressing changes or suture removal. Tissue glue is easy to use in outpatient departments and can reduce the need for health care staff, the number of hospital visits, and the risk of crossinfection.

\section{Ethics Statement}

This study was conducted with approval from the Ethics Committee of Wuhan Children's Hospital. This study was conducted in accordance with the declaration of Helsinki. All patients and parents were informed of the purpose of the study and their consent was obtained.

\section{Acknowledgments}

Hua Yuan and Yu-Zhao Zhang are co-first authors for this study.

\section{Funding}

Wuhan Municipal Health Planning Commission Clinical Research Grant Project (WX15A05).

\section{Disclosure}

The authors report no conflicts of interest in this work.

\section{References}

1. Ko AC, Satterfield KR, Korn BS, Kikkawa DO. Eyelid and periorbital soft tissue trauma. Facial Plast Surg Clin North Am. 2017;25 (4):605-616. doi:10.1016/j.fsc.2017.06.011

2. Rothan HA, Byrareddy SN. The epidemiology and pathogenesis of coronavirus disease (COVID-19) outbreak. J Autoimmun. 2020;109: 102433. doi:10.1016/j.jaut.2020.102433

3. WHO. World experts and funders set priorities for COVID-19 research. [EB/OL]. February 12, 2020. Available from: https://www. who.int/news-room/detail/12-02-2020-world-experts-and-funders-set -priorities-for-covid-19-research. Accessed May 3, 2021.

4. National Health Commission. Outbreak notification. [EB/OL]. march 6, 2020. Available from: http://www.nhc.gov.cn/xcs/yqtb/list_gzbd. shtml. Accessed May 3, 2021.

5. Mankowitz SL. Laceration management. J Emerg Med. 2017;53 (3):369-382. doi:10.1016/j.jemermed.2017.05.026

6. Braginsky L, Javellana M, Cleveland E, et al. Tissue adhesive compared with sterile strips after cesarean delivery: a randomized controlled trial. Obstet Gynecol. 2019;134(2):295-301. doi:10.1097/ AOG.0000000000003367

7. Buchweitz O, Frye C, Moeller CP, et al. Cosmetic outcome of skin adhesives versus transcutaneous sutures in laparoscopic port-site wounds: a prospective randomized controlled trial. Surg Endosc. 2016;30(6):2326-2331. doi:10.1007/s00464-015-4474-5

8. Osmond MH, Quinn JV, Sutcliffe T, et al. A randomized, clinical trial comparing butylcyanoacrylate with octylcyanoacrylate in the management of selected pediatric facial lacerations. Acad Emerg Med. 1999;6(3):171-177. doi:10.1111/j.1553-2712.1999.tb00151.x

9. Hines EQ, Cohen JS, Klein BL. Glue adhesives for repairing minor skin lacerations. Contemp Pediatr. 2013;30:25-34.

10. Quinn JV, Drzewiecki A, Li MM, et al. A randomized, controlled trial comparing a tissue adhesive with suturing in the repair of pediatric facial lacerations. Ann Emerg Med. 1993;22(7):1130-1135. doi:10.1016/S0196-0644(05)80977-1

11. Farion KJ, Osmond MH, Hartling L, et al. Tissue adhesives for traumatic lacerations: a systematic review of randomized controlled trials. Acad Emerg Med. 2003;10(2):110-118. doi:10.1197/aemj.10. 2.110

12. Eaglstein WH, Sullivan TP, Giordano PA, et al. A liquid adhesive bandage for the treatment of minor cuts and abrasions. Dermatol Surg. 2002;28(3):263-267. doi:10.1046/j.1524-4725.2002.01207.x

13. von Eckardstein AS, Lim CH, Dohmen PM, et al. A randomized trial of a skin sealant to reduce the risk of incision contamination in cardiac surgery. Ann Thorac Surg. 2011;92(2):632-637. doi:10.10 16/j.athoracsur.2011.03.132

14. Dumville JC, Coulthard P, Worthington HV, et al. Tissue adhesives for closure of surgical incisions. Cochrane Database Syst Rev. 2014;11:D4287.

15. Jenkins LE, Davis LS. Comprehensive review of tissue adhesives. Dermatol Surg. 2018;44(11):1367-1372. doi:10.1097/DSS.000000 0000001576

16. Farion K, Osmond MH, Hartling L, et al. Tissue adhesives for traumatic lacerations in children and adults. Cochrane Database Syst Rev. 2002;3:D3326. 
17. Kumar DA, Agarwal A, Jacob S, Lamba M, Packialakshmi S, Meduri A. Combined surgical management of capsular and iris deficiency with glued intraocular lens technique. J Refract Surg. 2013;29 (5):342-347. doi:10.3928/1081597X-20130415-05

18. Lin M, Coates WC, Lewis RJ. Tissue adhesive skills study: the physician learning curve. Pediatr Emerg Care. 2004;20(4):219-223. doi:10.1097/01.pec.0000121240.99242.72

19. Shaw C, Islam MN, Chakroborty $\mathrm{S}$, et al. Tissue adhesive in ophthalmology. J Indian Med Assoc. 2010;108(7):460-461.
20. Blondeel PN, Murphy JW, Debrosse D, et al. Closure of long surgical incisions with a new formulation of 2-octylcyanoacrylate tissue adhesive versus commercially available methods. Am J Surg. 2004;188 (3):307-313. doi:10.1016/j.amjsurg.2004.04.006

21. Singer AJ, Quinn JV, Hollander JE. The cyanoacrylate topical skin adhesives. Am J Emerg Med. 2008;26(4):490-496. doi:10.1016/j. ajem.2007.05.015

\section{Publish your work in this journal}

Clinical, Cosmetic and Investigational Dermatology is an international, peer-reviewed, open access, online journal that focuses on the latest clinical and experimental research in all aspects of skin disease and cosmetic interventions. This journal is indexed on CAS.
The manuscript management system is completely online and includes a very quick and fair peer-review system, which is all easy to use. Visit http://www.dovepress.com/testimonials.php to read real quotes from published authors. 